\title{
CRANKSHAFT DEVELOPMENT OF A TWO-STH
COMPRESSION-IGNITION ENGINE WITH CONTRA-RUNNING PISTONS
}

\section{LUBOMÍR DRÁPAL, PAVEL NOVOTNÝ, VÁCLAV Pİ̌̌TĚK, RICHARD AMBRÓZ}

Institute of Automotive Engineering, Brno University of Technology, Technická 2, CZ61669 Brno, Czech Republic, Tel.: +420 541142264 , Fax: +420 541143 354, E-mail: drapal@fme.vutbr.cz

\section{SHRNUTí \\ Tento článek se zabývá návrhem, porovnáním různých variant a výběrem vhodného řešení klikových hřídelů pro dvoudobý vznětový přeplňovaný letecký motor s protiběžnými písty a souproudým vyplachováním. Návrh variant klikových hř́idelů je proveden na základě analýzy vyvážení celého hnacího ústrojí a zahrnuje v sobě různé kombinace požadavků na pevnost, hmotnost a právě i vyvážení. Všechny varianty jsou s využitím postupů MKP a MBS podrobeny dynamickým simulacím pro celé spektrum provozních otáček a vhodné řešení je zvoleno na základě kritéria minimalizace torsního kmitání, únavové životnosti částí motoru a zatižení hlavních ložisek. \\ KLIICCVÁ SLOVA: DYNAMIKA HNACÍHO ÚSTROJÍ, KLIKOVÝ HŘÍDEL, DVOUDOBÝ MOTOR, VYVÁŽENÍ MOTORU, TORZNÍ KMITÁNÍ, ÚNAVOVÁ ŽIVOTNOST}

\section{ABSTRACT}

The paper is focused on designing and comparing different options, and then selecting the most suitable crankshaft design for a two-stroke $\mathrm{Cl}$ engine with contra-running pistons and through-flow scavenging. The crankshaft variants are based on analysis performed with the powertrain balance and include various combinations of requirements for strength, weight and balance. Applying FEM and MBS procedures, all variants undergo dynamic simulations across the whole spectrum of operation speeds. A suitable design is selected with reference to the criteria of minimizing torsional vibrations, fatigue life of individual engine parts, and the main bearing load.

KEYWORDS: POWERTRAIN DYNAMICS, CRANKSHAFT, TWO-STROKE ENGINE, ENGINE BALANCE, TORSIONAL VIBRATIONS, FATIGUE LIFE

\section{INTRODUCTION}

The engine in question is primarily intended for the aircraft industry, and this places extreme demands on efficiency parameters, weight, compactness, fuel consumption and reliability. In the past, there have been attempts to combine all these sometimes contradictory requirements and build two-stroke $\mathrm{Cl}$ supercharged engines. In the 1930s and beginning of the 1940s, Jumo 204-208 engines produced by German manufacturer Junkers became the most renowned. The design of these powertrains served as a model for the engine described below.

The developed crankshaft originates in a powertrain that is based on a two-stroke $\mathrm{Cl}$ engine with two opposing crankshafts. Each crankshaft has two crank pins opposed by $180^{\circ}$. Two rods are connected to it, and each of them is connected to one piston. The pistons of the opposite crank pins run opposed to each other in one cylinder - i.e. it is a two-cylinder engine.
The crankshafts are interconnected by a system of gear wheels that also serves as a propeller speed reducer.

This design has been selected for its compactness and resulting low weight. Two-stroke $\mathrm{Cl}$ engines also achieve the best rated specific effective fuel consumption. This is, however, conditional on a suitable design of engine timing mechanism. The given engine is fitted with through-flow scavenging enabling relatively perfect scavenging of the combustion chamber. Intake and exhaust ports are uncovered by pistons of one or the other crankshaft. These are therefore termed "intake" and "exhaust" crankshafts. The through-flow scavenging requires non-symmetric timing diagram, and the rotation of the "intake" crankshaft moves in relation to the "exhaust" crankshaft by a particular angle. High performance is ensured by a turbocharger and a supercharger (Roots type) that is necessary especially for engine starting. 


\section{ENGINE BALANCE ANALYSIS}

In order to evaluate the engine design, engine balance analysis is carried out. It is based on the following general assumptions:

crank mechanism is centric;

shape and size of crank mechanism parts are strictly

adhered to;

- weights of the same type of parts within the crank

mechanism are identical;

- the crank mechanism is absolutely rigid and does not deform;

acceleration due to gravity, and frictional forces are not taken into account.

The whole crank mechanism is reduced to mass points corresponding to the individual parts. Evaluation concerns a rotating mass as well as a reciprocating mass, particularly with respect to the resultant of their inertial forces and moments. For the powertrain design see Figure 1.

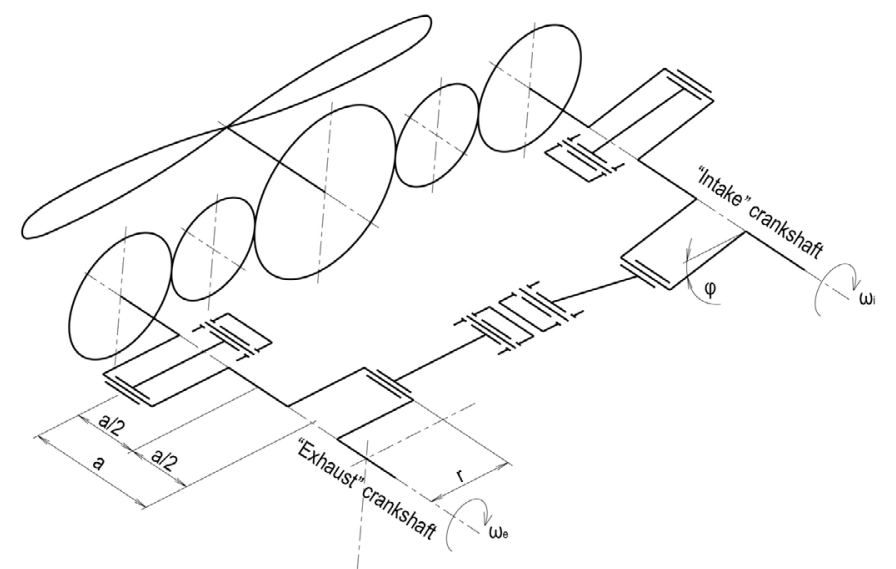

FIGURE 1: Powertrain scheme

OBRÁZEK 1: Schéma hnacího ústrojí

\subsection{ROTATING MASSES}

The resultant of inertial forces in a rotating mass is zero for both crankshafts, which is a logical result with the angle between connecting rod pins being $180^{\circ}$.

The moment vector is non-zero. It has a constant magnitude at steady-state speed and rotates in the direction of the crankshaft rotation. This moment adds to the load on the crankshaft main bearings, and its influence can be reduced by using two or four counterweights on each crankshaft. The size of such counterweights, or their influence on reducing the resultant of the moment of inertial forces of rotating masses, is restricted by the design. Regarding the piston design, the cylinder liners are rather long which reduces the possibility of using a larger counterweight diameter.

The total size of the moment of inertial forces of rotating masses, with respect to the engine influence as a whole on the frame, is given by the moment vector sum of both crankshafts, and for mutual crankshaft offset by an angle $\varphi=14^{\circ}$ it amounts to approximately $24 \%$ of one crankshaft value.

\subsection{RECIPROCATING MASSES - FIRST ORDER EXCITATION}

The sum of primary inertial forces of each reciprocating mass is zero for each crankshaft, and therefore also for the engine as a whole.

Moments of the forces are sinusoidal and the resultants of both crankshafts are phase-shifted by $180^{\circ}+\varphi$ (see Figure 2). An algebraic sum for the whole engine is also sinusoidal with $24 \%$ amplitude in proportion to one crank mechanism ("intake" or "exhaust"). The resultant vector tends to rotate the whole aggregate in the axis that is perpendicular to the cylinder plane and its effect can theoretically be eliminated by a suitable counterbalance unit with two contra-rotating balancing shafts.

\subsection{RECIPROCATING MASSES - SECOND ORDER EXCITATION}

The secondary resultant of the inertial forces of reciprocating mass is non-zero for the engine of the given concept. Its amplitude is approximately $48 \%$ of the amplitude of one crank mechanism (this applies for mutual crankshaft offset by angle $\varphi=14^{\circ}$, see Figure 3). This effect of forces causes the vibration of the whole aggregate in the axis of the cylinders with sinusoidal wave and double frequency when compared to the crankshaft rotation frequency. For the engine as a whole, these inertial forces can be totally or partially reduced by means of two contra-rotating balancing shafts of a slightly different design than for moments of the primary inertial forces in the reciprocating mass.

Moments of the secondary inertial forces in the reciprocating mass are zero for both crank mechanisms, and also for the whole engine.

\subsection{EXISTING STRUCTURE EVALUATION}

The resultants of the inertial forces are linearly dependent on the weight and the length of the reciprocating or rotating mass. They are also quadratically dependent on the engine speed. The piston assembly is a relatively big unit of an untypical design and its weight is about $1.5 \mathrm{~kg}$.

In order to balance the engine as a whole, it seems ideal if the angle of mutual crankshaft offset $\varphi$ is $0^{\circ}$. However, such requirement is in contradiction to the function of the designed valveless distribution system with asymmetrical timing and through-flow scavenging. Such angle of $\varphi$ therefore introduces three free force and moment effects into the dynamic effects of the whole aggregate.

Balancing of moments of the rotating mass inertial forces, although limited by the highest possible diameter of the 


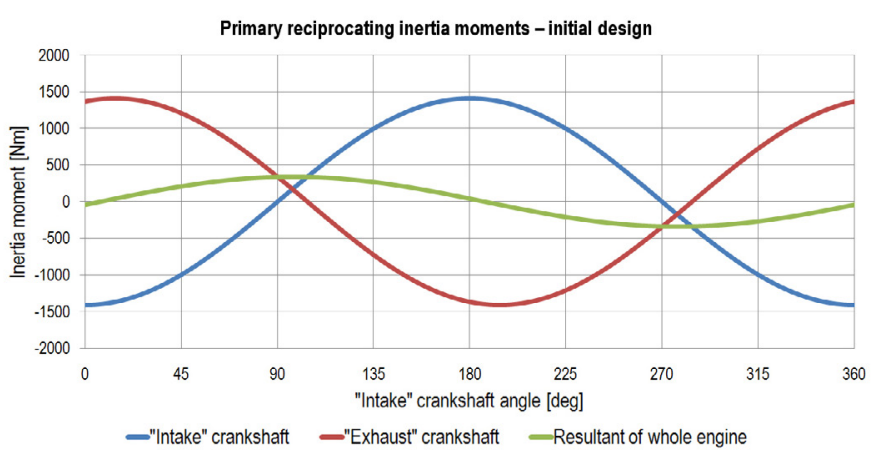

FIGURE 2: Primary reciprocating inertia moments - initial powertrain design OBRÁZEK 2: Momenty prvního řádu setrvačných sil posuvných hmot výchozího návrhu hnacího ústrojí

crankshaft counterweights, should theoretically result in partial load removing from the main bearings, which was verified in MBS. With resultants of the inertial effects of reciprocating masses, primary moments and secondary forces, the additional balancing seems to be unrealistic in the current stage of the project. In the next phases of the powertrain development, they should be considered when designing the engine mount in the frame.

\section{POWERTRAIN DYNAMIC ANALYSES}

In previous development stages, dynamic analyses of the initial powertrain design were already carried out (see Figure 4). However, they did not provide sufficient results for the designed rated output, particularly when considering fatigue of the crankshaft and output shaft [1]. This is why new crankshaft variants were designed, the output shaft was strengthened, and an elastic mounting of the pulley in the compressor drive was designed to reduce torsional vibrations of the "intake" crankshaft. Evaluation of the new crankshaft variants is the particular focal point of this paper.

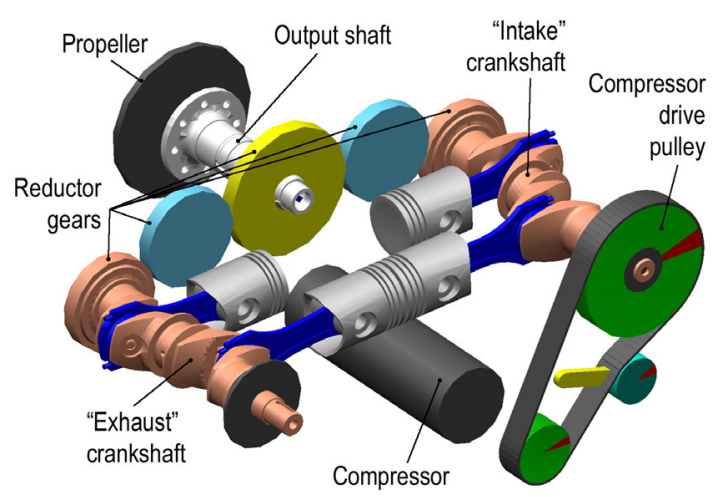

FIGURE 4: MBS model of initial powertrain design OBRÁZEK 4: MBS model výchozího návrhu hnacího ústrojí

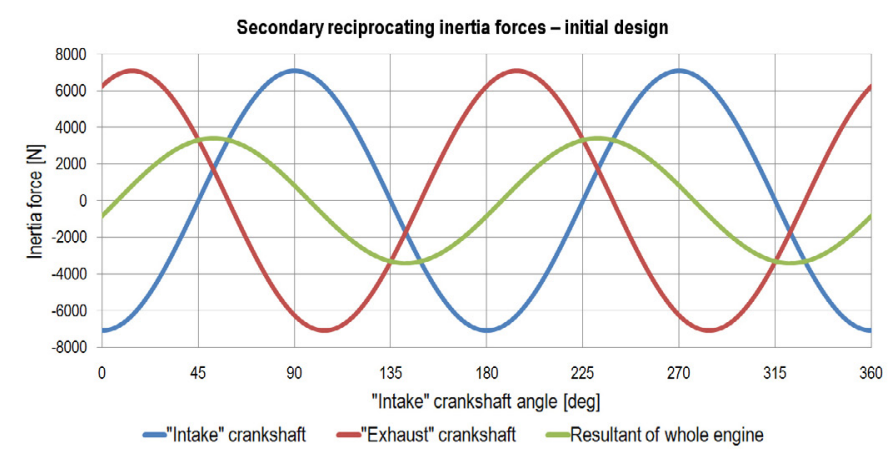

FIGURE 3: Secondary reciprocating inertia forces - initial powertrain design OBRÁZEK 3: První rád setrvačných sil posuvných hmot výchozího návrhu hnacího ústrojí

\subsection{NEW CRANIKSHAFT VARIANTS}

The crankshaft under development will only be successful if a specific limit value of the output weight $(\mathrm{kg}$ weight of the whole aggregate per rated output unit) is not exceeded. This is why the preferences for newly designed crankshafts are arranged in the following way (in descending order):

1. high strength;

2. low weight;

3. balance of moments of the inertial forces in the rotating mass. As far as material is concerned, only alloy steel can be used for the expected highest output. For a small-batch production, four variants of steel pre forged and completely machined crankshafts were suggested. Their designs include all possible combinations of the above preferences. Each variant can be found in Figures 5 and 6 and they are designated as follows:

"Light unbalanced" hereinafter LU $(7.521 \mathrm{~kg})$;

"Light balanced" hereinafter LB $(8.687 \mathrm{~kg})$;

"Heavy unbalanced" hereinafter HU $(8.277 \mathrm{~kg})$;

"Heavy balanced" hereinafter HB $(9.442 \mathrm{~kg})$.

Each variant has its specific weight, static and dynamic stiffness and level of balance. The designs even include oil ramps for pressure engine oil supply to the crank pins, whose openings are located as close to the neutral pin deflection axis as possible. The shape of these oil ramp openings is designed according to the previous partial strength analysis carried out for several possible designs. All crankshaft variants are applicable as both an "intake" and an "exhaust" shaft.

\subsection{DYNAMIC COMPUTATIONAL MODEL}

All following analyses are based on a dynamic computational model (virtual engine) created in MBS, where crankshafts and output shafts are used as linearly elastic bodies. These are modally reduced FEM models. Other engine parts are modelled as solid bodies, except for reducer gear wheels (see below).

The supercharger rotor is a solid rotor represented by an equivalent moment of inertia and predefined power input. 

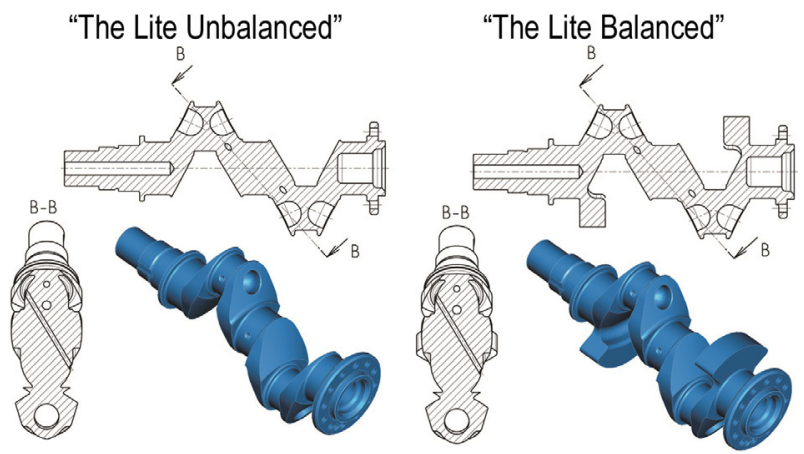

FIGURE 5: "The Lite" variants of new crankshaft design OBRÁZEK 5: „Lehké" varianty nového návrhu klikového hř́dele

The impact of the propeller is simplified to the form of a solid disc with equivalent moment of inertia. In the reducer model, there are elastic gear wheels with one degree of freedom and a defined stiffness and damping corresponding to the given gearing. The gearing model also includes force effects of radial and tangential forces.

The interaction between crankshafts and output shaft, and the engine block takes place via a non-linear hydrodynamic journal bearing model, where pre-calculated force databases obtained when solving a separate hydrodynamic problem are used.

The virtual engine is excited by means of cylinder pressure defined by calculation, and by means of inertial forces from moving parts. The simulation starts at $1650 \mathrm{rpm}$ and extends up to $4125 \mathrm{rpm}$. Such simulation is carried out on all crankshaft variants and the consequential comparison is based on a predefined output obtained from MBS.

In order to evaluate and compare different crankshaft variants, suitable criteria have to be selected. For these purposes, the following ones have been used:

- level of torsional vibration in the crankshafts;

- fatigue life;

- load of main bearings.

\subsection{CRANIKSHAFT TORSIONAL VIBRATION}

Torsional vibration is common to internal-combustion engine crankshafts. The crankshaft mechanism generates alternating torque due to alternating combustion pressure in conjunction with the alternating effect of reciprocating masses inertia. This torque results in vibration of the elastic crankshaft about the axis of rotation. This torsional vibration can cause cracking and crankshaft failure, and therefore it is a very dangerous crankshaft effect.

The results obtained from the harmonic analysis of torsional vibrations in the "intake" crankshaft of the LU variant are illustrated in Figure 7, which shows crankshaft angular deformation between the crankshaft pulley plane and gear
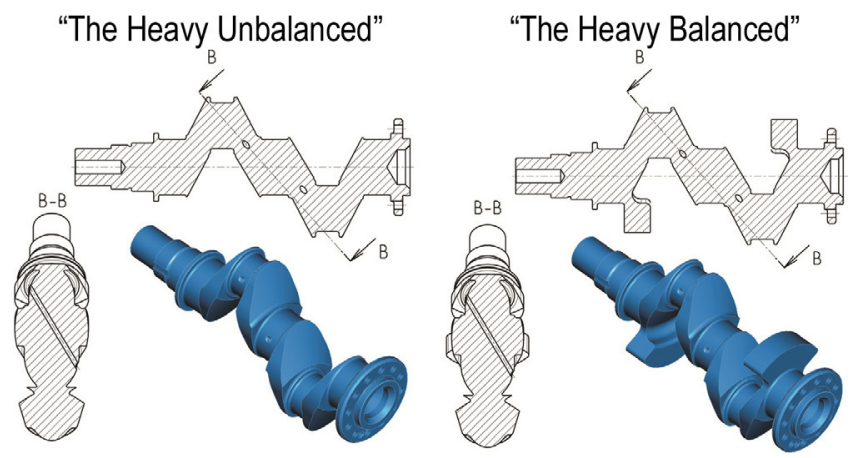

FIGURE 6: "The Heavy" variants of new crankshaft design OBRÁZEK 6: „Těžké" varianty nového návrhu klikového hrídele

wheel plane. It is clear that the fourth harmonic component of the torsional vibrations has a strong impact and reaches resonance below the highest speed. The resonance from the sixth harmonic component is evident below $2700 \mathrm{rpm}$. The eighth harmonic component shows resonance too, but its impact on the total shaft oscillation is considerably smaller.

Harmonic analysis of the torsional vibrations proved the theoretical assumptions, i.e. that the main orders play the

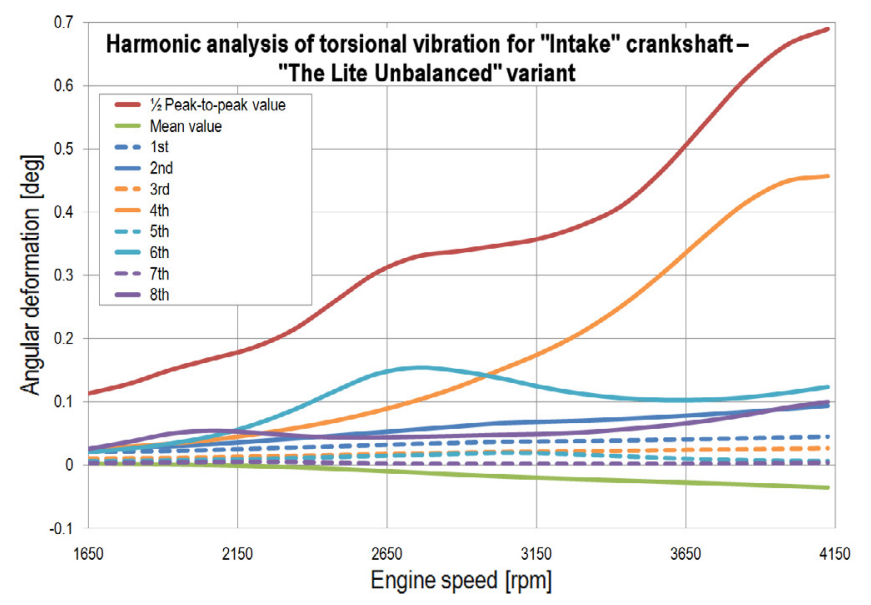

FIGURE 7: Harmonic analysis of torsional vibrations for "Intake" crankshaft - "The Lite Unbalanced" variant

OBRÁzEK 7: Harmonická analýza torsního kmitání "sacího" klikového hř́dele ve variantě "Lehká nevyvážená"

largest role in the vibrations (for the given engine concept these orders are integral multiples of two), their resonance speed goes down with the higher order of harmonic component as well as its amplitude. The synthesis is equal to half the size of the peak-to-peak value from the periodic torsional oscillation.

These analyses are performed for all crankshaft variants and the results are shown in Figure 8. This demonstrates the difference in oscillation range between the "intake" and "exhaust" shafts caused mainly by the supercharger as a robust rotor and its drive ensured by the "intake" crankshaft via the pulley and ribbed 

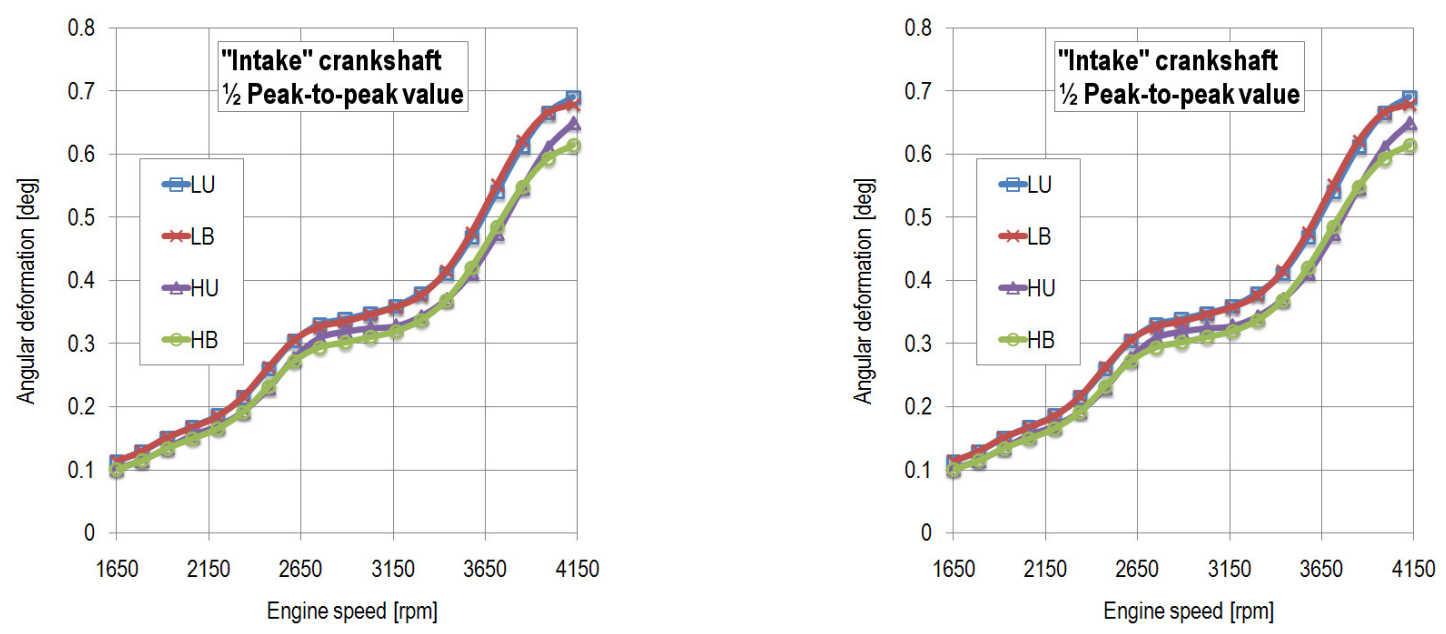

FIGURE 8: Torsional vibrations of all new crankshaft variants

OBRÁZEK 8: Torsní kmitání všech nových variant klikového hřídele
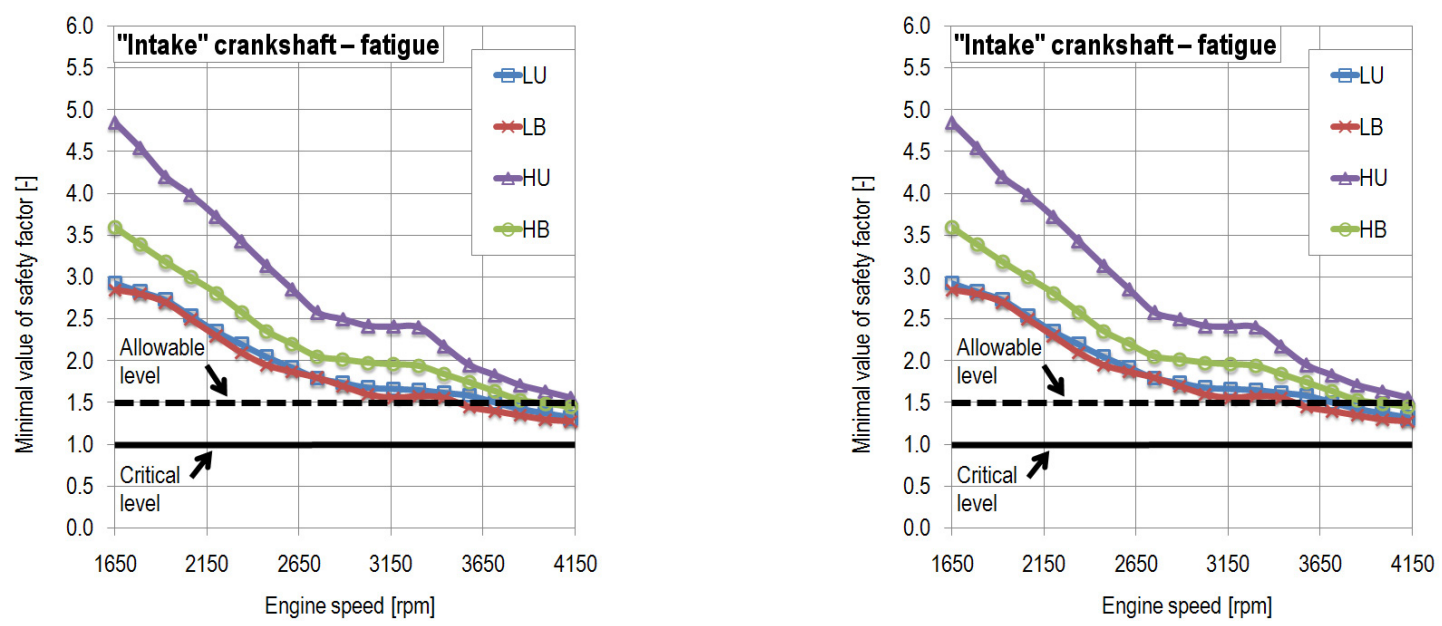

FIGURE 9: Minimal values of fatigue safety factor for whole engine speed range

OBRÁZEK 9: Závislost nejnižší hodnoty součinitele bezpečnosti vůči mezi trvalé pevnosti na otáčkách motoru

belt. The mentioned additional inertial mass lowers the natural frequency of the torsional system, and this also shifts the critical speeds corresponding to the low harmonic orders nearer to, or indeed within, the upper part of the operating speed range.

In order to compare individual variants and show the resistance to torsional vibrations, an "intake" crankshaft was selected because its greatest torsional deformation between crankshaft pulley plane and gear wheel plane is more than triple that of the "exhaust" shaft. In Figure 8, the difference between "light" and "heavy" variants is noticeable. Greater torsional displacement of the "light" variant is caused mainly by the lower torsional stiffness of crankshaft arms and connecting rod pins because of the influence of discharge holes.

Surprisingly, small differences were observed between the "balanced" and "unbalanced" variants. During the previous analyses a specific type of vibration was detected. Its source was later found in the oscillation of the counterweights. Subsequent strengthening of the point where the counterweight passes into the crank web resulted in an increase in the torsional stiffness which compensated even for the negative impact of the counterweight as an inertial mass decreasing the natural frequencies.

The torsional oscillation criterion is paradoxically best satisfied by the HB variant, followed by HU; however, the latter is $1.165 \mathrm{~kg}$ lighter.

\subsection{FATIGUE LIFE}

Dynamically stressed engine parts are exposed to a load varying with time and locally, which causes difficulties when defining the safety factor against a convenient limiting state. For commercially used powertrains, the limiting state of fatigue strength is chosen in most cases as the "unlimited fatigue life". MBS outputs (load history) can be favourably applied as input data to calculate fatigue. 
Preparing the calculations in the given program enables involvement of even structural and technological factors in high detail, e.g. the impact of the surface finish (or surface roughness) or chemical and heat treatment. Based on the preliminarily obtained modal coordinates (MBS) and modal tension (FEM), the software will calculate a modified Haigh diagram. Applying the critical cutting plane method, a crash point with the lowest safety factor is defined. This represents a relationship between the comparative equivalent tension (according to material) and the fatigue strength limit in the given node within the finite element system.

The calculation completed for all nodes is repeated several times for the whole operational speed range. As a result, we obtain safety factor relationships between the fatigue strength limit and the engine speed in critical areas of the crankshaft such as areas where main pins and crank pins pass into the crankshaft webs, and the area of oil ramp openings. For the detailed situation with respect to the individual crankshaft variants see Figure 9 . Comparison of the "intake" and "exhaust" shafts enables clear identification of differences. The displayed safety factors reflect the stresses caused by forces resulting from gas pressure, by inertial forces, as well as other dynamic processes characterised as oscillations, i.e. they also include the torsional oscillation. It is clear that considerable torsional oscillation, especially its fourth harmonic component, dramatically decreases the lowest safety factor levels at high engine speed.

An acceptable safety factor limit against the fatigue strength is determined primarily on the basis of the production tolerance, the spread of material characteristics, and simplifying assumptions of the computational model. When comparing the variants, only the HU variant did not exceed the limit at any point across the whole range of operational speeds. All variants are suitable as an "exhaust" crankshaft.

\subsection{MAIN BEARING LOAD}

Main bearing load is determined by combining the reactions to the load forces taking into account identical excitation by forces from gas pressure; it differs according to the stiffness and level of crankshaft balancing. We have to consider which parameter could be suitable for comparison of the individual variants. The following parameters can be used:

- reaction force;

relative eccentricity.

The above-mentioned reaction force term includes the magnitude of a fictitious single force caused by integration of a function of pressure distribution in the hydrodynamic lubrication layer. Relative eccentricity is defined as

$$
\varepsilon=\frac{2 e}{D-d}
$$

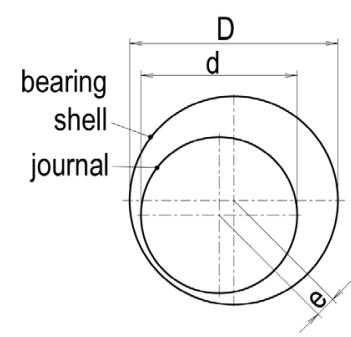

FIGURE 10: Journal bearing scheme OBRÁZEK 10: Schéma kluzného ložiska

where $e[\mathrm{~mm}]$ is the absolute eccentricity of the pin centre against the centre of the bearing shell, $D[\mathrm{~mm}]$ is the bearing shell diameter and $d[\mathrm{~mm}]$ the pin diameter (see Figure 10). An absolutely stiff pin and shell are assumed. If the centres of the pin and shell are identical, $\varepsilon=0$. If the pin and shell surfaces contact, the relative eccentricity reaches $\varepsilon=1$.

When the piston moves around the top dead centre, the crankshaft is subject to the greatest forces from gas pressure; however, at this moment, they have almost the same direction as the fictitious force induced by the counterweight centrifugal force. Such impact slightly increases the highest values of reaction forces in the bearing and almost eliminates the possibility of evaluating the balance efficiency according to this parameter. Regarding the bearing life, the highest relative eccentricity over the course of the working cycle seems the most important. This is also due to the fact that the bearing response (represented by a decrease in the oil film thickness) to the drive pulse is not immediate. For these reasons, the individual crankshaft variants are compared just according to the size of the maximum value of relative eccentricity in the main bearings, as well as minimum and average values.

Newly designed variants, i.e. "intake" and "exhaust" crankshafts, are then compared. Figures 11 to 13 summarize the results obtained in analyses of maximum and average relative eccentricity on the engine speed for all crankshaft variants.

Main bearings are numbered in accordance with standards, i.e. the first main bearing is located at the front crankshaft ending, the second one is positioned between the cylinders, and the third main bearing is near to the flange, i.e. in the area where the speed reducer gear wheel is mounted to the outlet shaft. The Figure shows that the second main bearing is the most loaded; the impact of forces from gas pressure dominates here, and thus the differences in relative eccentricities in individual variants are smaller than in the outer bearings. In bearings 1 and 3, there are more additional reactions, which are caused by the free moment vector of the inertial forces of rotating masses. Here, the differences in relative eccentricities in individual variants are more evident, especially at higher speed. The highest relative eccentricities can be found in the HU variant, and the lowest in the "light" variant. The HB variant falls between them. 

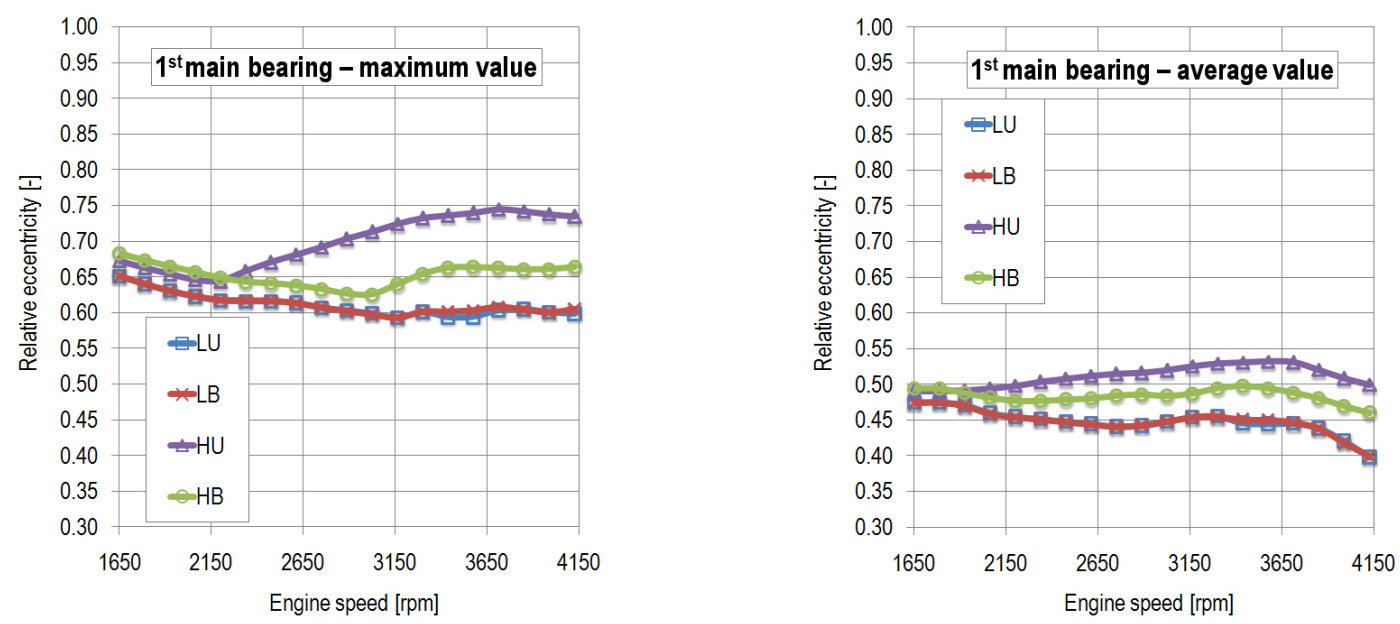

FIGURE 11: Maximum and average values of relative eccentricity at the first main bearing for whole engine speed range OBRÁZEK 11: Nejvyšší a průměrné hodnoty relativní excentricity prvního hlavního ložiska v závislosti na otáčkách motoru
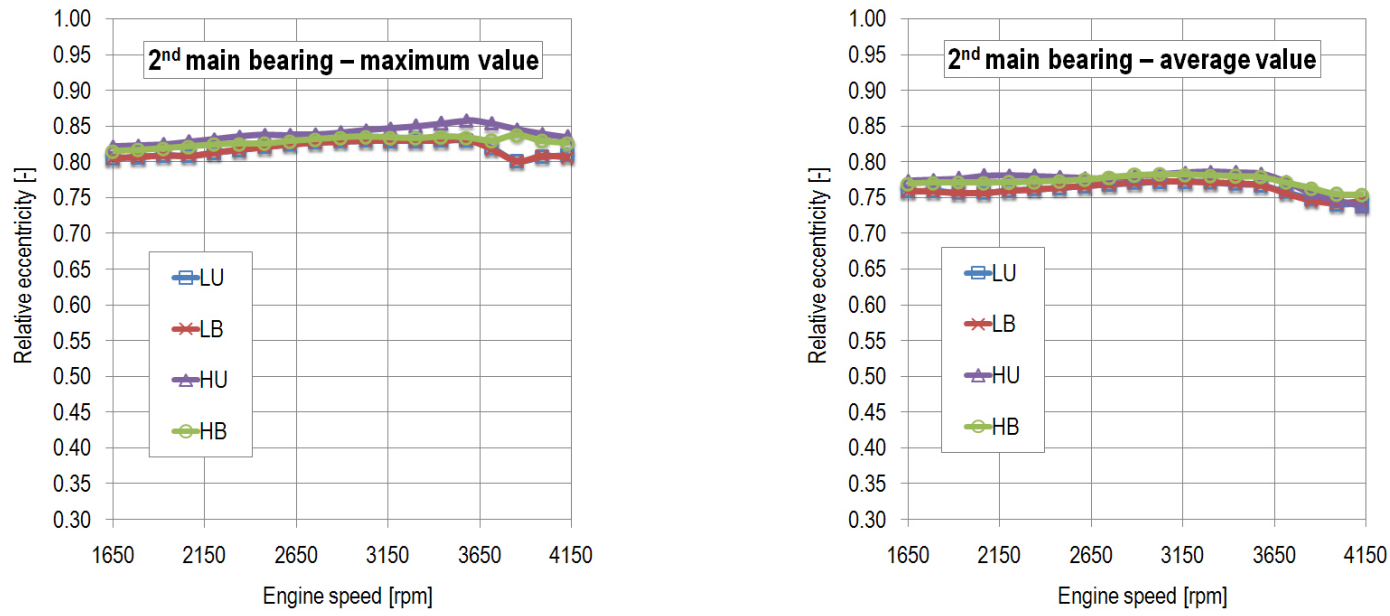

FIGURE 12: Maximum and average values of relative eccentricity at the second main bearing for whole engine speed range OBRÁZEK 12: Nejvyšší a průměrné hodnoty relativní excentricity druhého hlavního ložiska v závislosti na otáčkách motoru
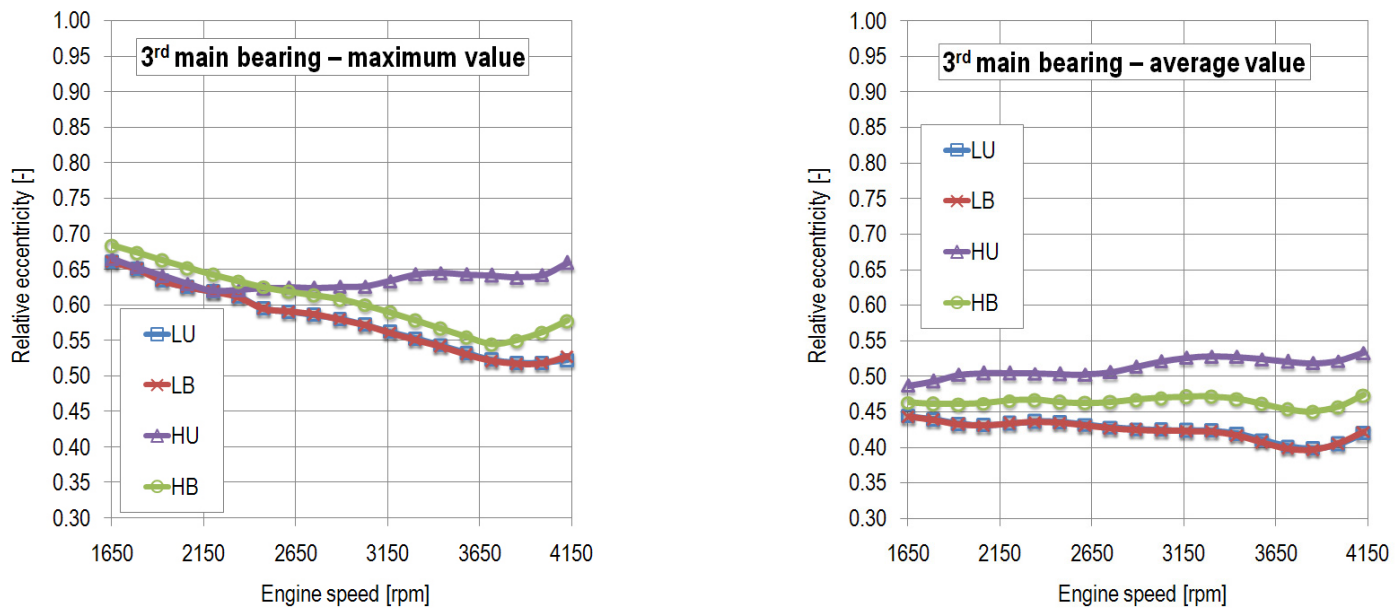

FIGURE 13: Maximum and average values of relative eccentricity at the third main bearing for whole engine speed range OBRÁZEK 13: Nejvyšší a průměrné hodnoty relativní excentricity třetího hlavního ložiska v závislosti na otáčkách motoruFigure 9: Minimal values of fatigue safety factor for whole engine speed range 
Even in the worst case, relative eccentricity amounts to approximately $\varepsilon=0.86$, and that is why all variants can be regarded as acceptable with respect to bearing load.

\section{CONCLUSION}

As the original powertrain design did not provide satisfactory results in the area of torsional vibrations and fatigue life, the output shaft was strengthened, adjustments to the mounting of supercharger drive pulley were performed, and four new crankshaft variants were designed. Each variant was designed as a completely machined steel shaft, and they differ in strength, weight and degree of balancing of the moment of the inertial forces in rotating mass. Thus, there are different combinations of requirements placed on the aircraft engine powertrain necessary for accurate defining of an optimum variant in the subsequent dynamic calculations.

Evaluation of dynamic simulations proved that the "intake" crankshaft in particular is subject to loading from substantial torsional vibrations due to the robust supercharger drive connected to its front part. These vibrations are lower in "heavy" variants, which demonstrate higher torsional stiffness because they do not have discharge holes in the crankpins. The most complex criterion for verifying total dynamic stress is represented by the fatigue life calculation. Over the full range of operating engine speeds, it is only the $\mathrm{HU}$ variant that remains within an acceptable safety factor with respect to fatigue strength limit. This is why only this variant can be regarded as acceptable. Other variants have either lower stiffness, or higher inertia characteristics which decrease the natural frequencies of vibrations, or these two effects were present simultaneously. If the influence of all crankshaft loads (inertia effects and combustion pressure effects) on main bearing relative eccentricity is taken into consideration, all variants are suitable.

In conclusion, for the designed rated power and selection criteria, the "heavy unbalanced" (HU) variant seems to be the most suitable one. The next goal is improvement of the crankshaft fatigue life, particularly at maximum engine speeds.

\section{ACKNOWLEDGEMENT}

Published results have been achieved with the financial help of the Ministry of Industry and Trade of the Czech Republic, project FR-TI1/580 - Research and Development of Two Stroke Diesel Engine with Contra-rotating Pistons and the Ministry of Education, Youth and Sports, project reg. no. CZ.1.05/2.1.00/01.0002 - NETME Centre - New Technologies for Mechanical Engineering.
LIST OF ABBREVIATIONS AND SYMBOLS

$\mathrm{Cl}$ compression-ignition

D bearing shell diameter [mm]

d pin diameter [mm]

e absolute eccentricity [mm]

FEM Finite Element Method

HB crankshaft variant "heavy balanced"

HU crankshaft variant "heavy unbalanced"

LB crankshaft variant "lite balanced"

LU crankshaft variant "lite unbalanced"

MBS Multi-Body System

$\varepsilon \quad$ relative eccentricity [-]

$\varphi \quad$ crankshaft offset angle $\left[^{\circ}\right]$

\section{REFERENCES}

[4] Novotný, P., Píštěk, V., Drápal, L. \& Ambróz, R. (2010). Cranktrain Development of Aircraft Diesel Engine, In: Blažek, J., Brabec, P., Voženílek, R. Proceedings - XLI. International Scientific Conference of Czech and Slovak University Departments and Institutions Dealing with the Research of Combustion Engines, Book's print, Czech republic, pp. 212-222. ISBN 978-80-7372-632-4

[5] Novotný, P. (2009). Virtual Engine -A Tool for Powertrain Development. Unpublished doctoral dissertation, Brno University of Technology, Czech republic.

[6] MSC (2006). ADAMS/Solver C++ Users Manual 2005r2, MSC. Software Corporation, California, 2006 